
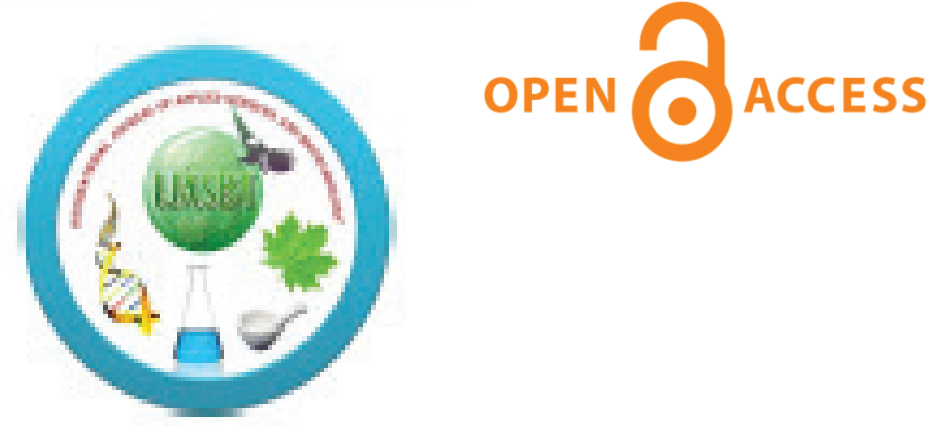

Available online at wwwijastht.org.

International Journal of Applied Sciences and Biotechnology A Rapid Publishing Journal

\begin{tabular}{|c|c|c|}
\hline \multicolumn{2}{|c|}{ APPUEO SCENCES } & BIOTECHNOLOSY \\
\hline $\begin{array}{l}\text { Blochemistry } \\
\text { Molecular biology } \\
\text { Microbiology } \\
\text { Cell blology } \\
\text { Cytology } \\
\text { Genetles } \\
\text { Patholosy } \\
\text { Medicinal chemistry } \\
\text { Polymer sdences } \\
\text { Analytical chemistry } \\
\text { Natural chemistry }\end{array}$ & $\begin{array}{l}\text { Immunobiolosy } \\
\text { Bioinformatics } \\
\text { Nowel drug delivery system } \\
\text { Pharmacology } \\
\text { Neuroblology } \\
\text { Bio-physics } \\
\text { Botany } \\
\text { Zoology } \\
\text { Allied science } \\
\text { Earth sdence }\end{array}$ & $\begin{array}{l}\text { Microbial biotechnolosy } \\
\text { Med ical biotechnology } \\
\text { Industrial biotechnolosy } \\
\text { Enviranmental biotechnolosy } \\
\text { Nanotechnology }\end{array}$ \\
\hline
\end{tabular}

If any queries or feedback, then don't hesitate to mail us at: editor.ijasbt:@gmail.com 


\section{Natural Resource Management System: A Global Need}

$\mathrm{N}$ ature is full of resources, but, their optimum utilization with their proper conservation is the demand of present time. How to manage the natural resources for the sustainable development of the ecosystem is an important task for the researchers and policy makers. Any country of the world is not less important on the point view of natural resources, whereas, types of resources may vary from one region to other region. The judicious utilization of biodiversity for the benefit of mankind is the proper way to progress day by day. Proper planning and research for the development is the back bone of economic development. The economic activity should be the entry point with the communities. While biological monitoring and conservation education must also be initiated from the start, economic benefits win the trust and respect of community members and get them interested in resource management issues faster. Nepal is very rich in biodiversity; unfortunately Nepal is unable to utilize their maximum benefits due to lack of proper- policy, knowledge and planning. Forums that bring together the government, NGOs, private sector, community groups, and research institutions are essential to open dialogue and effective feedback on policy implementation strategies. A few International NGOs such as ANSAB (Asia Network for Sustainable Agriculture and Bio-resources) and ICIMOD (International Center for Integrated Mountain Development) have a catalytic role to play in community based resource management, but local and national level institutions need to be integrated into the process from the start for long-term sustainability of the activities and replication.

ANSAB is working for the conservation of biodiversity and the improvement of livelihoods across South Asia. It places community empowerment and economic incentives at the heart of its approach, believing that as people benefit from natural resources they become more motivated to protect them and vice-versa. ANSAB implements a variety of innovative solutions in line with this core conviction, such as the creation of enterprises based on the sustainable use of natural resources, especially Non Timber Forest Products (NTFPs), and the establishment of payment-schemes for ecosystem services, especially Reducing Emissions from Deforestation and Forest Degradation, Forest Conservation, Sustainable Management of Forests and Carbon Stock Enhancement. It does so in the context of global climate change, which continues to threaten the environmental and economic progresses achieved so far in Nepal as in the rest of the world. ANSAB is widely regarded as a trailblazer and a leading organization in the region, its innovative approach having been recognized by numerous awards and its expertise being regularly sought by development agencies, national governments and international NGOs. It has notably 
pioneered Forest Stewardship Council (FSC) certification in Nepal and introduced the concept of subgroups to ensure that ultra-poor and marginalized people benefit from the natural resources of their communities. ANSAB moreover demonstrated a remarkable capacity to effectively work in remote and socio-politically difficult areas, even at times when most NGOs found them too difficult to operate.

International Center for Integrated Mountain Development (ICIMOD) was formed in December 1983 with an objective to conserve the unique biodiversity of the region known as the Hindu Kush Himalayas. The Hindu Kush Himalayan $(\mathrm{HKH})$ region is one of the most disaster-prone areas in the world. Here, floods account for more than a third of the total natural disasters in the region and affect millions of people. The impact of climate change is expected to be more significant in the HKH region, which will only increase the frequency and magnitude of flood events in the coming years. Statistics show that the number of people killed per flood event is significantly higher in Asia, and floods have a greater effect on poor and marginalized communities in the mountains of the $\mathrm{HKH}$ region. The recent deadly floods in Bangladesh, India, Nepal, and Pakistan are a testimony to the region's vulnerability to the unprecedented wrath of both riverine and flash floods. While riverine floods are a regular occurrence in the plains of Bangladesh and India, the physical environment of the Hindu Kush Himalayas makes flash floods a more common phenomenon. Intense rains, cloudbursts, glacial lake outbursts, and landslide outbursts can trigger devastating flash floods in the middle mountains. Widespread deglaciation in the region has led to the formation and rapid growth of many glacial lakes. These lakes can burst their boundaries as a result of internal instabilities or external triggers in a process known as a glacial lake outburst flood (GLOF), which can cause immense flooding downstream. Similar to this, landslides resulting from intense rainfall in combination with geological instabilities can cause the ephemeral damming of rivers. The outbreak of lakes created by such damming is another type of flash flood common in the region. Each year, hundreds of lives and billions of dollars worth of property and high-cost infrastructure are lost and much-scarce agricultural land is destroyed in the region. Many of the floods in the region cross borders, and transboundary floods are known to lead to greater loss of lives and properties. To minimize the devastating effects of floods, new technologies and approaches, as well as greater transboundary cooperation, are required. The organization works along with regional programs in the eight member countries it represents, with its stated mission being "To enable sustainable and resilient mountain development for improved and equitable livelihoods through knowledge and regional cooperation." Among the programs overseen by ICIMOD is the concept of Transboundary Landscapes, where the emphasis is on conserving natural resources, such as forests, wetlands, watersheds and farming systems, and the people who rely on these resources, irrespective of country boundaries. For example the Kailash Sacred Landscape Conservation and Development Initiative (KSLCDI) is a collaborative transboundary program between India, China and Nepal, incorporating the southwestern section of Tibet (an autonomous region of China), the Far-Western region of Nepal that borders Tibet, and the northeastern section of India's Uttarakhand State. Covering an area of around 31,000 square kilometers, the region includes numerous sites of religious 
significance, such as Holy Mount Kailash and Lake Mansarovar, both of which are in Tibet, but which attract pilgrims from Nepal and India. In fact these holy sites are considered to be the ultimate destination by Hindu, Buddhist, Jain, Sikh and Bon pilgrims, and have been for countless generations. Today, a number of factors, including climate change and population growth, threaten to degrade these areas if conservation steps aren't taken. With tourism being a significant income generator for Nepal, the importance of conserving the country's natural resources and promoting sustainable development is paramount, and this is where the combined knowledge and scientific resources of ICIMOD members and supporters can really make a difference. In spite of the working plans of various agencies, the present disaster in Uttarakhand, India alarms us to be careful for the proper management of natural resources.

We can remember the recent devastating floods and landslides in Uttarakhand, the North Indian state, which caused multi-day cloudburst centered on the country's worst natural disaster in June 2013. Though some parts of Himachal Pradesh, Haryana, Delhi and Uttar Pradesh in India, some regions of Western Nepal, and some parts of Western Tibet also experienced heavy rainfall and over $95 \%$ of the casualties occurred in Uttarakhand. 16 July 2013 was the black day due to presumed dead of more than 5,700 people, according to figures provided by the Uttarakhand government. Destruction of bridges and roads left about 100,000 pilgrims and tourists trapped in the valleys leading to three of the four Hindu Chota Char Dham pilgrimage site. The Indian Air Force, the Indian Army, and paramilitary troops evacuated more than 110,000 people from the flood ravaged area. From 14 to 17 June 2013, the Indian state of Uttarakhand and adjoining area received heavy rainfall, which was about 375 percent more than the benchmark rainfall during a normal monsoon. This caused the melting of Chorabari Glacier at the height of 3800 metres, and eruption of the Mandakini River which led to heavy floods near Gobindghat, Kedar Dome, Rudraprayag district, Uttarakhand, Himachal Pradesh and Western Nepal, and acute rainfall in other nearby regions of Delhi, Haryana, Uttar Pradesh and some parts of Tibet. The upper Himalayan territories of Himachal Pradesh and Uttarakhand are full of forests and snow-covered mountains and thus remain relatively inaccessible. They are home to several major and historic Hindu and Sikh pilgrimage sites besides several tourist spots and trekking trails. Heavy rainfall for four consecutive days as well as melting snow aggravated the floods. Warnings by the India Meteorological Department predicting heavy rains were not given wide publicity beforehand, causing thousands of people to be caught unaware, resulting in huge loss of life and property. In the city of Dehra Dun, capital of Uttarakhand, this was the wettest June day for over five decades. Death and damage Landslides, due to the floods, damaged several houses and structures, killing those who were trapped. The heavy rains in large flashfloods and massive landslides. Entire villages and settlements such as Gaurikund and the market town of Ram Bada, a transition point to Kedarnath, have been obliterated, while the market town of Sonprayag suffered heavy damage and loss of lives. Pilgrimage centres in the region, including Gangotri, Yamunotri, Kedarnath and Badrinath, the hallowed Hindu Chardham (four sites) pilgrimage centers, are visited by thousands of devotees, especially after the month of May onwards. Over 70,000 people were stuck in various regions because of damaged or blocked roads. People in other important locations like the Valley of flowers, 
Roopkund and the Sikh pilgrimage centre Hemkund were stranded for more than three days. National Highway 58, an important artery connecting the region was also washed away near Jyotirmath and in many other places. Because summers have more number of tourists, the number of people impacted is substantial. The roads were seriously damaged at more than 450 places, resulting in huge traffic jams, and the floods caused many cars and other vehicles to be washed away. On June 18, more than 12,000 pilgrims were stranded at Badrinath, the popular pilgrimage center located on the banks of the Alaknanda River. Rescuers at the Hindu pilgrimage town of Haridwar on the river Ganga recovered bodies of 40 victims washed down by the flooded rivers as of June 21 2013. Bodies of people washed away in Uttarakhand were found in distant places like Bijnor, Allahabad and Bulandshahr in Uttar Pradesh. Searching for bodies who died during the extreme natural fury of June in Kedar valley continued for several months and even as late as September, 2013, about 166 bodies were found in highly decomposed state during fourth round of search operations. Therefore, fast action plan regarding the management of the natural resources should be taken in to consideration by the initiative Government, International and national NGOs for sustainable growth.

Umesh P. Shrivastava

International Journal of Applied Sciences and Biotechnology (2013) 1(3), i-ii

DOI: $10.3126 /$ ijasbt.v1i3.8656 